\title{
First report of adult Hyalomma marginatum rufipes (vector of Crimean-Congo haemorrhagic fever virus) on cattle under a continental climate in Hungary
}

\author{
Sándor Hornok ${ }^{1 *}$ and Gábor Horváth²
}

\begin{abstract}
Background: South Hungary is being monitored for the northward spreading of thermophilic ixodid species, therefore ticks were collected from cattle and wild ruminants (red, fallow and roe deer) in the autumn of 2011.

Findings: Besides indigenous species (1185 Dermacentor reticulatus and 976 Ixodes ricinus), two Hyalomma marginatum rufipes males were found on two cows, in September eight days apart.

Conclusions: This is the northernmost autochthonous infestation of the type host (cattle) with H. m. rufipes, vector of Crimean-Congo haemorrhagic fever virus. The present findings are suggestive of the moulting success of this Afro-Mediterranean tick species in a continental climate in Central Europe.
\end{abstract}

Keywords: Hyalomma marginatum rufipes, Cattle, Continental climate, Crimean-Congo haemorrhagic fever

\section{Background}

Within Central Europe Hungary is especially suitable for studying the northward spreading of thermophilic tick species, since it lacks high mountain ranges present along the same latitude in surrounding countries (i.e. the Alps and the Carpathians). Concerning environmental factors that influence tick distribution, south-western Hungary has the highest mean winter temperature (above $-1^{\circ} \mathrm{C}$ ) and precipitation (above $800 \mathrm{~mm}$ per year) in the country. Here, along the Croatian side of the border, Mediterranean ixodid species are known to occur [1]. In addition, a locally warmer continental climate may also allow future establishment of ticks transported by migratory birds from even larger distances [2]. Therefore it was decided to monitor south Hungary for emerging tick species. The study area was selected by taking into account places of cattle keeping, game reserves and the most likely future occurrence of Hyalomma marginatum in Hungary according to prediction models [3].

\footnotetext{
*Correspondence: Hornok.Sandor@aotk.szie.hu

'Department of Parasitology and Zoology, Faculty of Veterinary Science, Szent István University, Budapest, Hungary

Full list of author information is available at the end of the article
}

Ticks were collected during the autumn (SeptemberNovember) of 2011 from 20 beef cattle grazing outside, as well as from fresh carcasses of 82 red deer (Cervus elaphus), 20 fallow deer (Dama dama) and 6 roe deer (Capreolus capreolus) in south-western Hungary. All evaluated cattle were raised locally, and never left the country. Their contact with game animals can be excluded. The study area measured $20 \times 30 \mathrm{~km}$ and is found at geographical coordinates $46^{\circ} 20^{\prime} \mathrm{N}, 17^{\circ} 10^{\prime} \mathrm{E}$ (Figure 1: site 4). All specimens of ticks were removed by forceps and put into $70 \%$ ethanol. Species were identified according to standard keys [4].

\section{Findings}

A total of 2163 adult ticks were collected from cattle and wild ruminants. The majority of ticks from cattle were Dermacentor reticulatus (442 of 524: $84 \%$ ), with a lower abundance of Ixodes ricinus (80 of 524: 15\%). The proportion of these two species was more equilibrated on game animals (743 of 1639: 45\% D. reticulatus, 896 of 1639: $55 \%$ I. ricinus). Apart from indigenous tick species, two Hyalomma marginatum rufipes males were also found on two cows, at the end of September eight

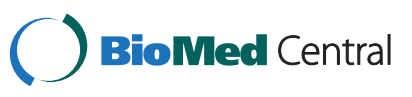




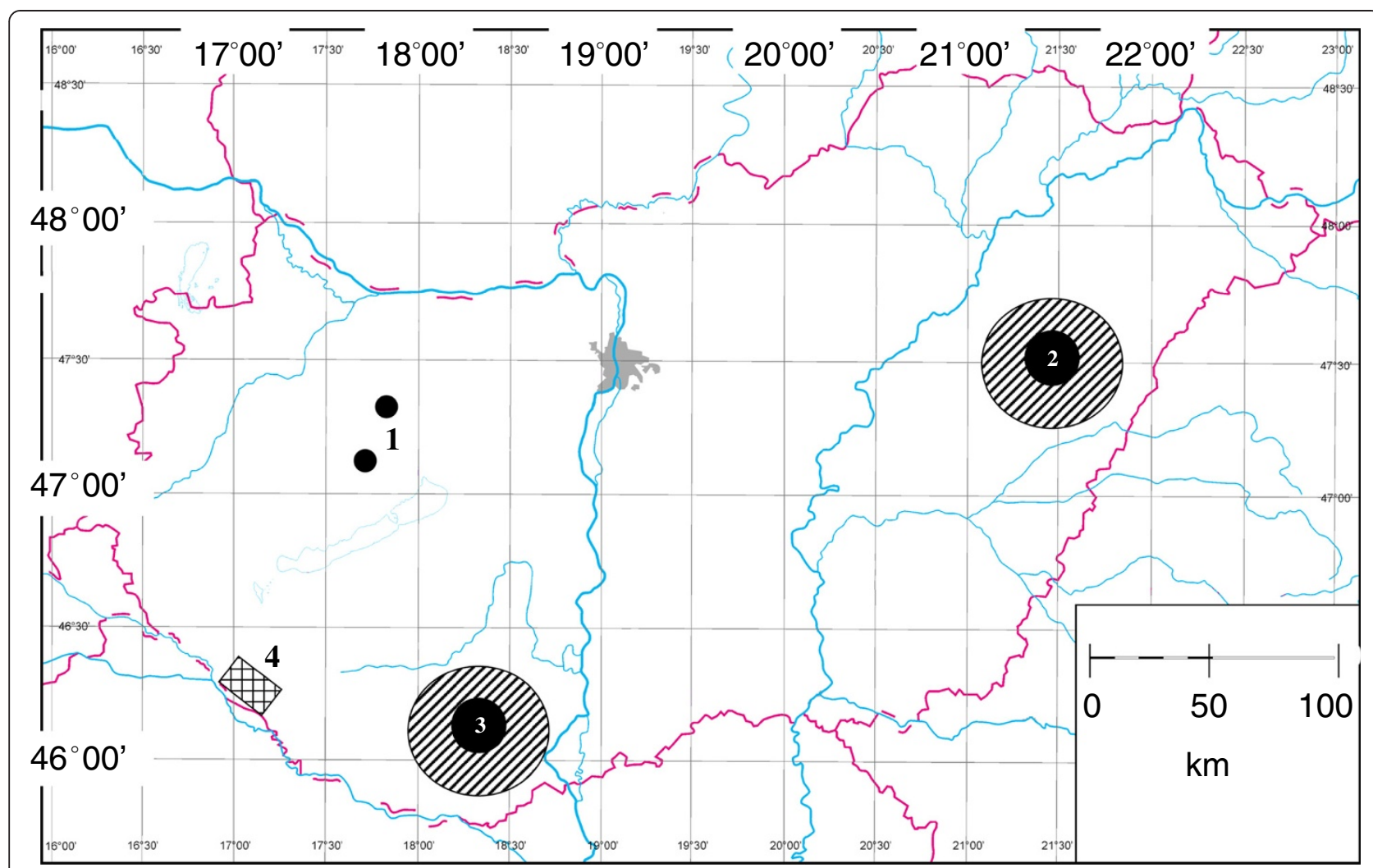

Figure 1 Map of Hungary showing in chronological order regions for: (1) CCHF virus isolation in 1972, (2) autochthonous bovine and ovine CCHF seropositivities in 1973, (3) one human CCHF case in 2004; and (4) the study area. Large, ruled circles indicate potential areas for infectious source.

days apart. These ticks were identified by the apparent dense dorsal punctuation and setae around the spiracles (Figure 2). To the best of our knowledge, this is the first recent report of infestation with adults of any Hyalomma spp. - in the same area, on two occasions - outside their known geographical range in Europe.
The main host of adult $H$. m. rufipes is cattle, but wild ungulates are also frequently infested [4]. However, during the present survey this tick species was absent from game animals. One factor that may have contributed to this is that Hyalomma spp. prefer open country habitats [5], therefore are more likely to attach to cattle which

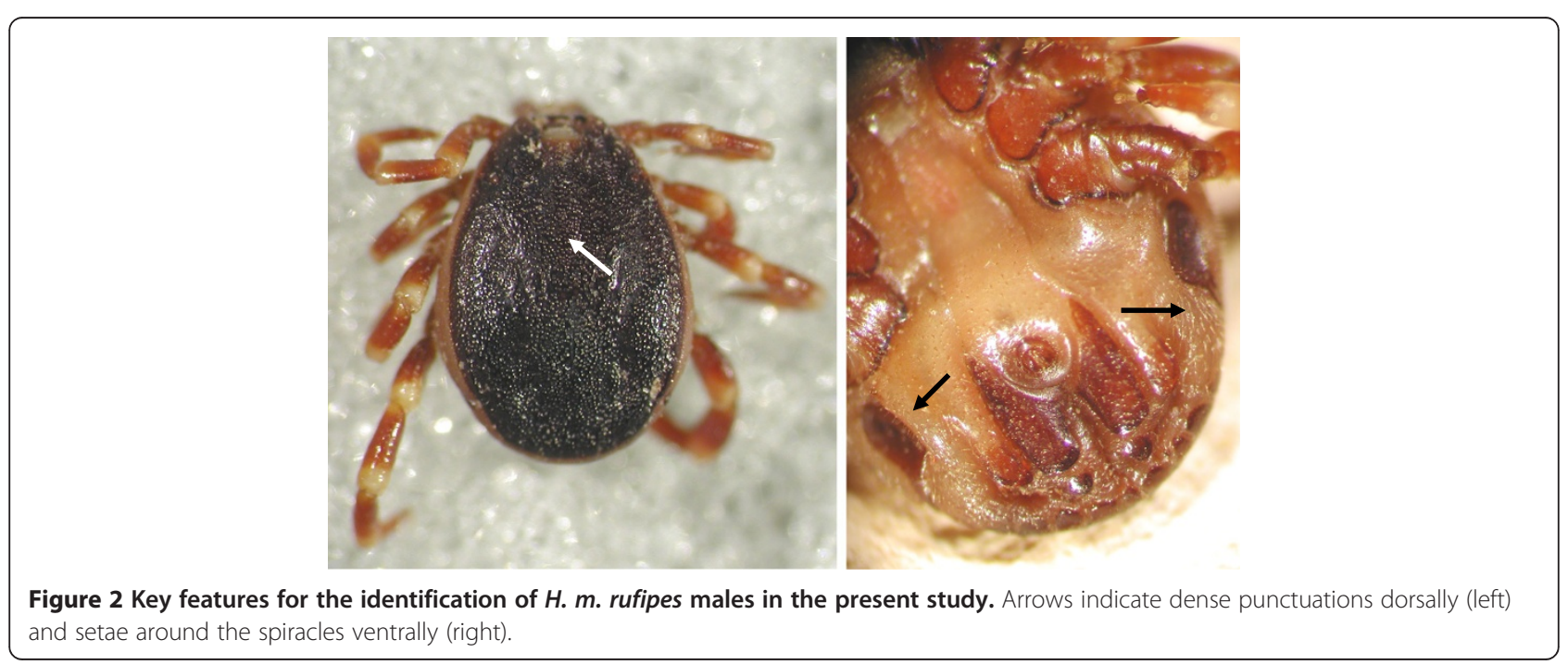


permanently graze on pastures. Similarly, $D$. reticulatus as an open country tick species [5] was significantly (Fisher's exact test: $\mathrm{P}<0.0001)$ more prevalent on cattle during the present survey, than on game animals partly with forested habitats.

$H$. m. rufipes is the most widespread species of the genus in Africa, but decades-old data attest to its occurrence along the northern latitude of Hungary in east Europe (including Russia: Caspian Sea region, Ukraine: Black Sea region), and to the south in Balkan countries such as Romania, Serbia, Bosnia-Herzegovina and Macedonia [6-8]. The most likely scenario for $H$. m. rufipes found on occasions in any part of Europe is importation of immature stages by migratory birds, arriving during the spring from the south [7].

Consequently, adults of this tick species are expected to be most active during the summer, as reported in Romania south-east of Hungary [6]. However, during an extensive tick collection in the study area during the preceding summer no Hyalomma specimens were found [9]. A plausible explanation for finding $H$. m. rufipes adults in the autumn is that cumulative temperatures are lower in Hungary, than in regions towards the south where $H$. m. rufipes is indigenous. In such conditions Hyalomma nymphs engorging at the time of migratory bird arrival in the spring may need much longer to moult [10].

In Europe $H$. m. rufipes subadults collected from migratory birds were reported several times, up to the northern latitude of Norway [11]. However, accounts of the occurrence of adult Hyalomma individuals north of the Mediterranean basin are scarce. One $H . m$. rufipes male was reported from a horse in an oceanic climate in the Netherlands [12], and one female $H$. lusitanicum also from a horse in a continental climate in Germany [13]. The origin of another, questing $H$. m. marginatum in Germany was reported to be doubtful [13]. The establishment of Hyalomma populations in the north are limited by factors (most notably by cumulative autumn temperatures) that affect moulting to the adult stage, and not by extremely cold winter temperatures which can be tolerated by post-moult adults [10]. In particular, the geographical range of $H$. m. rufipes can extend to areas with up to 120 days of frost annually [14]. Consequently, even small local populations may establish from nymphs dispersed by migrating birds, as reported in Russia [14].

The most severe risk posed by the presence of Hyalomma spp. is the transmission of the zoonotic CrimeanCongo haemorrhagic fever (CCHF) virus for which they are considered to be the primary vectors [15]. To be specific, epidemiological studies showed that $H$. m. rufipes may harbour different genotypes of CCHF virus naturally, and in certain regions this tick subspecies is thought to play a leading role in the maintenance of CCHF endemicity $[16,17]$. As demonstrated experimentally, H. $m$. rufipes is able to take up, to maintain (both transstadially and transovarially) and to inoculate CCHF virus [18-20].

It was postulated that - based on the rare emergence of Hyalomma adults - future outbreaks of CCHF will involve Western Europe [21]. Accordingly, the sporadic appearance of exotic Hyalomma spp. in Hungary may also be relevant to the fact that autochthonous and northernmost occurrence of CCHF in Central Europe was reported from Hungary [22]. In particular, the virus was isolated in 1972 [23] and one person contracted the disease in 2004 [24] in counties of Hungary next to the one where $H . m$. rufipes was presently found (Figure 1: sites 1,3). In 1973 seropositivity to CCHF virus was also detected in aboriginally Hungarian cattle and sheep [25] (Figure 1: site 2).

\section{Conclusions}

Infestations of cattle with adults of $H$. m. rufipes, vector of CCHF virus, were recorded for the first time in Central Europe. The present findings are suggestive of the moulting success of Hyalomma nymphs (transported by migratory birds) under continental climate. Since Hyalomma adults were collected in an area predicted to have a higher risk for the future establishment of $H$. marginatum [3], data reported here also highlight the importance of predictive models. At the same time, these results support the need for continuous tick surveillance in similar regions, where exotic/emerging tick species are more likely to occur, which should be part of an integrated approach to monitor vector-borne diseases in Europe [26].

\section{Abbreviation}

CCHF: Crimean-Congo haemorrhagic fever.

\section{Competing interests}

The author(s) declare that they have no competing interests.

\section{Authors' contributions}

$\mathrm{SH}$ collected ticks and identified tick species, wrote the manuscript. $\mathrm{GH}$ also collected ticks. Both authors read and approved the manuscript.

\section{Acknowledgements}

The authors are grateful to Dr. Jenő Kontschán for his indispensable help in making Figure 2. This study was partially funded by EU grant FP7-261504 EDENext and is catalogued by the EDENext Steering Committee as

EDENext064 (http://www.edenext.eu). The contents of this publication are the sole responsibility of the authors and do not necessarily reflect the views of the Eureopean Commission. Sándor Hornok received Bolyai János scholarship from the Hungarian Academy of Sciences.

\section{Author details}

'Department of Parasitology and Zoology, Faculty of Veterinary Science, Szent István University, Budapest, Hungary. ${ }^{2}$ Veterinary Authority, Nagyatád, Hungary. 
Received: 11 June 2012 Accepted: 4 August 2012

Published: 13 August 2012

\section{References}

1. EFSA Panel on Animal Health and Welfare: Scientific opinion on geographic distribution of tick-borne infections and their vectors in Europe and the other regions of the Mediterranean Basin. EFSA Journal 2010, 8:1723.

2. Hoogstraal H, Kaiser MN, Traylor MA, Gaber S, Guindy E: Ticks (Ixodidea) on birds migrating from Africa to Europe and Asia. Bull World Health Organ 1961, 24:197-212.

3. Estrada-Peña A, Martínez Avilés M, Muñoz Reoyo MJ: A population model to describe the distribution and seasonal dynamics of the tick Hyalomma marginatum in the Mediterranean Basin. Transbound Emerg Dis 2011, 58:213-223.

4. Estrada-Peña A, Bouattour A, Camicas J-L, Walker AR: Ticks of domestic animals in the Mediterranean region: a guide to identification of species. Zaragoza, Spain: University of Zaragoza; 2004.

5. Uspensky I: Preliminary observations on specific adaptations of exophilic ixodid ticks to forests or open country habitats. Exp Appl Acarol 2002, 28:147-154.

6. Feider Z: Hyalomma (Hyalomma) plumbeum. Acaromorpha, Suprafamilia Ixodoidea. Fauna Republicii Populare Romane: Arachnida 1965, 5:342-355. in Romanian.

7. Apanaskevich DA, Horak IG: The genus Hyalomma Koch, 1844. V. Reevaluation of the taxonomic rank of taxa comprising the $\mathrm{H}$. (Euhyalomma) marginatum Koch complex of species (Acari: Ixodoidea) with redescription of all parasitic stages and notes on biology. Intern J Acarol 2008, 34:13-42.

8. Omeragic J: Ixodid ticks in Bosnia and Herzegovina. Exp App/ Acarol 2011, 53:301-309.

9. Hornok S, Horváth G, Jongejan F, Farkas R: Ixodid ticks on ruminants, with on-host initiated moulting (apolysis) of Ixodes, Haemaphysalis and Dermacentor larvae. Vet Parasitol 2012, 187:350-353.

10. Gray JS, Dautel H, Estrada-Peña A, Kahl O, Lindgren E: Effects of climate change on ticks and tick-borne diseases in Europe. Interdiscip Perspect Infect Dis 2009, :1-12. article ID 593232.

11. Hasle G, Bjune G, Edvardsen E, Jakobsen C, Linnehol B, Røer JE, Mehl R, Røed KH, Pedersen J, Leinaas HP: Transport of ticks by migratory passerine birds to Norway. J Parasitol 2009, 95:1342-1351.

12. Nijhof AM, Bodaan C, Postigo M, Nieuwenhuijs H, Opsteegh M, Franssen L, Jebbink $F$, Jongejan F: Ticks and associated pathogens collected from domestic animals in the Netherlands. Vector-Borne Zoonotic Dis 2007, 7:585-595.

13. Kampen H, Poltz W, Hartelt K, Wölfel R, Faulde M: Detection of a questing Hyalomma marginatum marginatum adult female (Acari, lxodidae) in southern Germany. Exp Appl Acarol 2007, 43:227-231.

14. Hoogstraal H: African Ixodoidea - I. Ticks of the Sudan. Washington, DC: US Department of the Navy, Bureau of Medicine and Surgery; 1956:480-489.

15. Whitehouse CA: Crimean-Congo hemorrhagic fever. Antiviral Res 2004, 64:145-160

16. Camicas JL, Cornet JP, Gonzalez JP, Wilson ML, Adam F, Zeller HG: CrimeanCongo hemorrhagic fever in Senegal. Latest data on the ecology of the CCHF virus. Bull Soc Pathol Exot 1994, 87:11-16. in French.

17. Zeller HG, Cornet JP, Diop A, Camicas JL: Crimean-Congo hemorrhagic fever in ticks (Acari: Ixodidae) and ruminants: field observations of an epizootic in Bandia, Senegal (1989-1992). J Med Entomol 1997, 34:511-516.

18. Hoogstraal $\mathrm{H}$ : The epidemiology of tick-borne Crimean-Congo hemorrhagic fever in Asia, Europe, and Africa. J Med Entomol 1979, 15:307-417.

19. Shepherd AJ, Swanepoel R, Cornel AJ, Mathee O: Experimental studies on the replication and transmission of Crimean-Congo hemorrhagic fever virus in some African tick species. Am J Trop Med Hyg 1989, 40:326-331.

20. Zeller HG, Cornet JP, Camicas JL: Experimental transmission of CrimeanCongo hemorrhagic fever virus by west African wild ground-feeding birds to Hyalomma marginatum rufipes ticks. Am J Trop Med Hyg 1994, 50:676-681.

21. Mild M, Simon M, Albert J, Mirazimi A: Towards an understanding of the migration of Crimean-Congo hemorrhagic fever virus. J Gen Virol 2010, 91:199-207.
22. Ergönül O: Crimean-Congo haemorrhagic fever. Lancet Infect Dis 2006, 6:203-214.

23. Molnár E: Occurrence of tick-borne encephalitis and other arboviruses in Hungary. Geographia Medica 1982, 12:78-120.

24. OEK: Krími-Kongó haemorrhágiás láz Görögországban. Epinfo 2008, 15:313-315. in Hungarian.

25. Horváth S: Krími haemorrhagiás láz $(\mathrm{KHL})$ elleni antitestek előfordulása Magyarországon. Orv Hetil 1974, 115:1214. in Hungarian.

26. Braks M, van der Giessen J, Kretzschmar M, van Pelt W, Scholte EJ, Reusken C, Zeller H, van Bortel W, Sprong H: Towards an integrated approach in surveillance of vector-borne diseases in Europe. Parasit Vectors 2011, 4:192.

\section{doi:10.1186/1756-3305-5-170}

Cite this article as: Hornok and Horváth: First report of adult Hyalomma marginatum rufipes (vector of Crimean-Congo haemorrhagic fever virus) on cattle under a continental climate in Hungary. Parasites \& Vectors 2012 5:170.

\section{Submit your next manuscript to BioMed Central and take full advantage of:}

- Convenient online submission

- Thorough peer review

- No space constraints or color figure charges

- Immediate publication on acceptance

- Inclusion in PubMed, CAS, Scopus and Google Scholar

- Research which is freely available for redistribution 